\title{
Medial Branch Neurotomy in Management of Chronic Spinal Pain: Systematic Review of the Evidence
}

\author{
Laxmaiah Manchikanti, MD*, Vijay Singh, MD**, Bradley D. Vilims, MD\#, Hans C. Hansen, MD\#", \\ David M. Schultz, MD* and David S. Kloth, MD**
}

Zygapophysial or facet joints have been implicated as cause of low back, mid back, upper back and neck pain with referred pain. Cervi$\mathrm{cal}$, thoracic and lumbar facet joints are innervated by the medial branches of the dorsal rami. Zygapophysial (facet) joints have been implicated as the source of chronic pain in $15 \%$ to $45 \%$ of the patients with chronic low back pain, $54 \%$ to $60 \%$ of the patients with chronic neck pain and $48 \%$ of the patients with thoracic pain.

A systematic review of the evidence of effectiveness of radiofrequency denervation in the management of chronic spinal pain was undertaken. This review included randomized clinical trials, as well as non-randomized or observational studies in the analysis. Literature search included MEDLINE, EMBASE, systematic reviews, narrative reviews, cross-references to the reviews and various published trials; and peer reviewed abstracts from scientific meetings during the past two years. An algorithmic approach was followed in study evaluation with a description of inclusion and exclusion criteria. A set of high-performing scales or checklists pertaining to randomized clinical trials and observational trials derived from the Agency for Healthcare Research and Quality (AHRQ) was utilized; Systems to Rate the Strength of Scientific Evidence. Qualitative analysis was conducted, using five levels of evidence for effectiveness of medial branch neurotomy.

Our search strategy identified over 1,000 citations as the result of electronic and manual screening. A total of 7 randomized trials of radiofrequency neurotomy for spinal pain were identified. However, only 4 related to medial branch neurotomy. Two of the four met the inclusion criteria. Among the multiple observational studies considered for inclusion, 4 prospective evaluations were included in the systematic review. In addition, 3 retrospective evaluations were also included. Two randomized trials comprised of 27 patients receiving active treatment. The first study consisted of cervical facet joint pain and the second consisted of lumbar facet joint pain. Both studies showed positive results. Similar to randomized trials, prospective, as well as retrospective evaluations showed positive evidence, both in short-term and long-term.

The results of this systematic review of 2 well-designed randomized trials, 4 prospective well-designed trials without randomization and 3 retrospective evaluations provided strong evidence that radiofrequency denervation offers short-term relief and moderate evidence of long-term relief of pain with chronic low back, thoracic and neck pain of facet joint origin.

Keywords: Back pain, neck pain, thoracic pain, spinal pain, facet joints, zygapophysial joints, medial branches, radiofrequency denervation, medial branch neurotomy, randomized controlled trial, prospective trial, retrospective evaluation, systematic review
Among the chronic pain problems, spinal pain emanating from lumbar, thoracic and cervical spine constitutes the majority of the problems (1-13). Kuslich et al (14) identified zygapophysial (facet) joints as capable of transmitting pain in the low back. The concept that facet joints are involved in the etiology of low back pain was described by Goldthwait (15) in 1911. Since then, multiple investi-

From Pain Management Center of Paducah, Paducah, KY; Pain Diagnostics Associates, Niagara, WI; Denver Pain Management, Wheat Ridge, CO; The Pain Releif Centers, Conover, NC; MAPS Pain Clinic, Minneapolis, MN; and Connecticut Pain Care, CT. *Dr. Manchikanti is the medical director at Pain Management Center of Paducah, **Dr. Singh is the medical director at the Pain Diagnostics Associates, ${ }^{\#}$ Dr. Vilims is an interventional pain pysician at Denver Pain Management, ${ }^{\#}$ Dr. Hansen is the medical director at The Pain Releif Centers, *Dr. Schultz is the medical director at MAPS Pain Clinic and $*$ Dr. Kloth is medical director of Connecticut Pain Care. Address correspondence: Laxmaiah Manchikanti, MD, 2831 Lone Oak Road, Paducah, KY 42003. E-mail: drm@apex.net

Funding: No external financial support was provided. gators have implicated zygapophysial or facet joints as cause of low back, mid back and upper back, and neck pain with referred pain (16). In experimental studies, cervical, thoracic and lumbar facet joints have been evaluated by intraarticular joint injections under fluoroscopic guidance (17-20). These injections demonstrated that capsular distention results in local and referred pain. Referral patterns for the cervical, thoracic and lumbar facet joints have been presented based on the results of these injections (17-20). Multiple investigators showed lumbar facet joints as capable of being a source of pain in the low back and referred pain in the lower extremity in normal volunteers; cervical facet joints as capable of being a source of neck pain, headache and upper extremity pain (17-25). Cervical, thoracic and lumbar facet joints are innervated by the medial branches of the dorsal rami (16, 26-30). There is no evidence that facet joint pain can be diagnosed by clinical examination or by medical imaging (17, 31-34). These joints can be blocked either by intraarticular injections or by anesthetizing the medial 
branches of the dorsal rami that innervate the target joint. In accordance with the criteria established by the International Association for the Study of Pain (35), zygapophysial (facet) joints have been implicated as the source of chronic pain in $15 \%$ to $45 \%$ of the patients with chronic low back pain $(34,36-40), 54 \%$ to $60 \%$ of the patients with chronic neck pain (41-43) and $48 \%$ of the patients with thoracic pain (44). These prevalence numbers are derived from the only available means of establishing a diagnosis of facet joint pain by diagnostic blocks of the putatively offending joint. These may be blocks of the joint itself or of the nerves that innervate it. Further, these may be placebo-controlled blocks or comparative local anesthetic blocks. Specificity, sensitivity, lack of reliability of single blocks and reliability of comparative local anesthetic blocks against placebo have been shown $(16,45-49)$.

Facet joint pain may be managed by either intraarticular injections, medial branch blocks or neurolysis of medical branches. Conflicting results have been reported by intraarticular injections of facet joints (50-54), medial branch blocks (53-55) and radiofrequency neurotomy of medial branches (56-61). Multiple systematic and narrative reviews also have yielded mixed results $(1,62-67)$.

Healthcare decisions are increasingly being made on research-based evidence, rather than on expert opinion or clinical experience alone. Thus, it is essential to examine the systematic approaches to assessing the strength of scientific evidence in modern medicine. However, evidencebased medicine, as well as systematic reviews have been misunderstood and misinterpreted. Evidence-based medicine is a loose term which has been used based not only on the necessity to present a particular view, but also based on personal philosophy, bias, and conjecture. The pioneering group of evidence based medicine in the late 70 s, led by David Sackett, proposed the term critical appraisal to describe the application of the basic rules of the evidence (68). A current definition of evidence-based medicine is the conscientious, explicit and judicious use of current best evidence in making decisions about the care of individual patients. Thus, evidence-based medicine is essentially what most clinicians have been trying to practice all their working lives. The practice of evidence-based medicine requires the integration of individual clinical expertise with the best available external clinical evidence from systematic research. Decisions that affect the care of patients should be made with a due weight according to all valid, relevant information. However, in contrast to the philosophy of evidencebased medicine, most systematic reviews utilized only ran- domized controlled trials even though systematic analysis is increasingly utilizing observational studies, as well as other types of evidence $(69,70)$. Admittedly, meta-analysis restricted to RCTs is usually preferred to meta-analyses of observational studies (71-73). However, the number of published meta-analyses concerning observational studies in health has increased substantially with 678 from 1955 to 1992, to more than 400 in 1996 alone (70). In many situations, randomized designs are not feasible, and only data from observational studies are available (74). An observational study is defined as an etiologic or effectiveness study using data from an existing database, a cross-sectional study, a case series, a case-controlled design, a design with historic controls, or a cohort design (75). Further, observational data is essential to assess the effectiveness of an intervention in a community as opposed to the special setting of a controlled trial (76). However, in interventional pain management, all the systematic reviews thus far have utilized only randomized controlled trials $(63,77-80)$.

In an Agency for Healthcare Research and Quality (AHRQ) Publication (81), for evaluating systems related to rating the quality of individual articles, the authors defined important domains and elements for four types of studies, which included systematic reviews, randomized clinical trials, observational studies, and diagnostic test studies. To arrive at a set of high-performing skills or checklist pertaining to systematic reviews, the authors took account of five key domains which included study question, search strategy, inclusion and exclusion criteria, data extraction and funding or sponsorship. In AHRQ evaluation, only one checklist fully addressed all seven domains, whereas two additional checklists and one scale addressed six of the seven domains $(81,82)$. Based on the five key domains as described by AHRQ (81), a look at multiple systematic reviews available in the literature failed to meet criteria on many of the aspects, such as study question, which should clearly delineate the type of intervention and the type of condition with appropriate outcome; search strategy which should include all the available evidence, including MEDLINE, EMBASE, reviews and other hand search methodology; inclusion and exclusion criteria which should include all the studies, but most all of them have included only randomized controlled clinical trials and some have included inappropriate diagnostic criteria; poor data extraction; and finally, funding and sponsorship issues. There has been only one systematic review of randomized clinical trials for efficacy of radiofrequency procedures for the treatment of spinal pain by Geurts et al (63). Unfortunately, this was marred with inappropriate methodology, inaccurate conclusions, fol- 
lowed by criticism $(65,66)$. Geurts et al $(63)$ included a total of six studies $(57,58,60,83-85)$, two of which $(83,84)$ were dorsal root ganglion radiofrequency studies, and a third study was intraarticular facet denervation (85). Thus, only three studies were facet radiofrequency, one of which was cervical and the remaining two were lumbar $(57,58$, 60 ). Geurts et al (62) in their results showed that all six trials met the inclusion criteria. They also stated that "this small number, along with clinical and technical heterogeneity precluded statistical analysis. All studies, whether high or low quality, reported positive outcomes." In contrast to the description in the results section, they concluded that there is only moderate evidence that radiofrequency lumbar facet denervation is more effective for chronic low back pain than placebo, and there was only limited evidence existent for efficacy of radiofrequency neurotomy in chronic cervical zygapophysial joint pain after flexion/extension injury.

Thus, we considered that there is paucity of evidence for systematic reviews of medial branch neurotomy in the management of chronic spinal pain. This systematic review was undertaken to assess the effectiveness of radiofrequency denervation in the treatment of spinal pain of facet joint origin.

\section{METHODS}

To follow the modern evidence and the true definition of evidence-based medicine, we have included in this systematic review not only the randomized clinical trials, but also observational studies, including cross-sectional studies, case-controlled studies, retrospective and other observational investigations. Our literature search included MEDLINE, EMBASE, systematic reviews, narrative reviews, cross-references to the reviews and various published trials; and peer reviewed abstracts from scientific meetings during the past two years. All the literature available through early 2002 was utilized. The search strategy consisted of radiofrequency with emphasis on chronic pain/low back pain/neck pain/mid back or thoracic pain and/or medial branch neurotomy/facet joint/zygapophysial joint pain. Further, the inclusion of the evaluations were limited to only the studies describing chronic pain of duration of at least three months and retrospective analysis including a minimum of 50 patients.

\section{Strength of Evidence}

For evaluating systems related to rating the quality of in- dividual articles, or describing AHRQ publication, which extensively evaluated systems to rate the strength of scientific evidence (81). This document described important domains and elements for systems to rate the quality of individual articles for randomized clinical trials and observational studies.

\section{Data Extraction}

Study evaluation and inclusion and exclusion algorithmic approach is shown in Table 1. Under this, if study population inclusion/exclusion criteria or appropriate diagnostic criteria were not met, the study was eliminated from consideration for the review.

Methodologic quality assessment was performed as described in Table 2. A set of high-performing scales or checklists pertaining to RCTs by assessing their coverage of the seven key domains as described in Table 2 were utilized. These included study population, randomization, blinding, interventions, outcomes, statistical analysis, and funding or sponsorship. For observational studies, the six key domains as described in Table 2 were utilized which included study population, comparability of subjects, exposure or intervention, outcome measurement, statistical analysis and funding or sponsorship. A score of 4 or more for randomized trials and a score of 3 or more was required to meet inclusion criteria. Studies were also eliminated if there were no appropriate outcomes or statistical analysis. Thus, for a study to be included, it had to meet at least 4 of 7 criteria for randomized and 3 of 5 criteria as non-randomized trials. Modified quality abstraction forms described by AHRQ were utilized.

\section{Qualitative Analysis}

Qualitative analysis was conducted, using five levels of evidence for effectiveness of medial branch neurotomy.

Level I - Conclusive: Research-based evidence with multiple relevant and high-quality scientific studies or consistent reviews of meta-analyses.

Level II - Strong: Research-based evidence from at least one properly designed randomized, controlled trial of appropriate size (with at least 60 patients in smallest group); or research-based evidence from multiple properly designed studies of smaller size; or at least one randomized trial, supplemented by predominantly positive 
Table 1. Study evaluation (inclusion/exclusion) algorithm

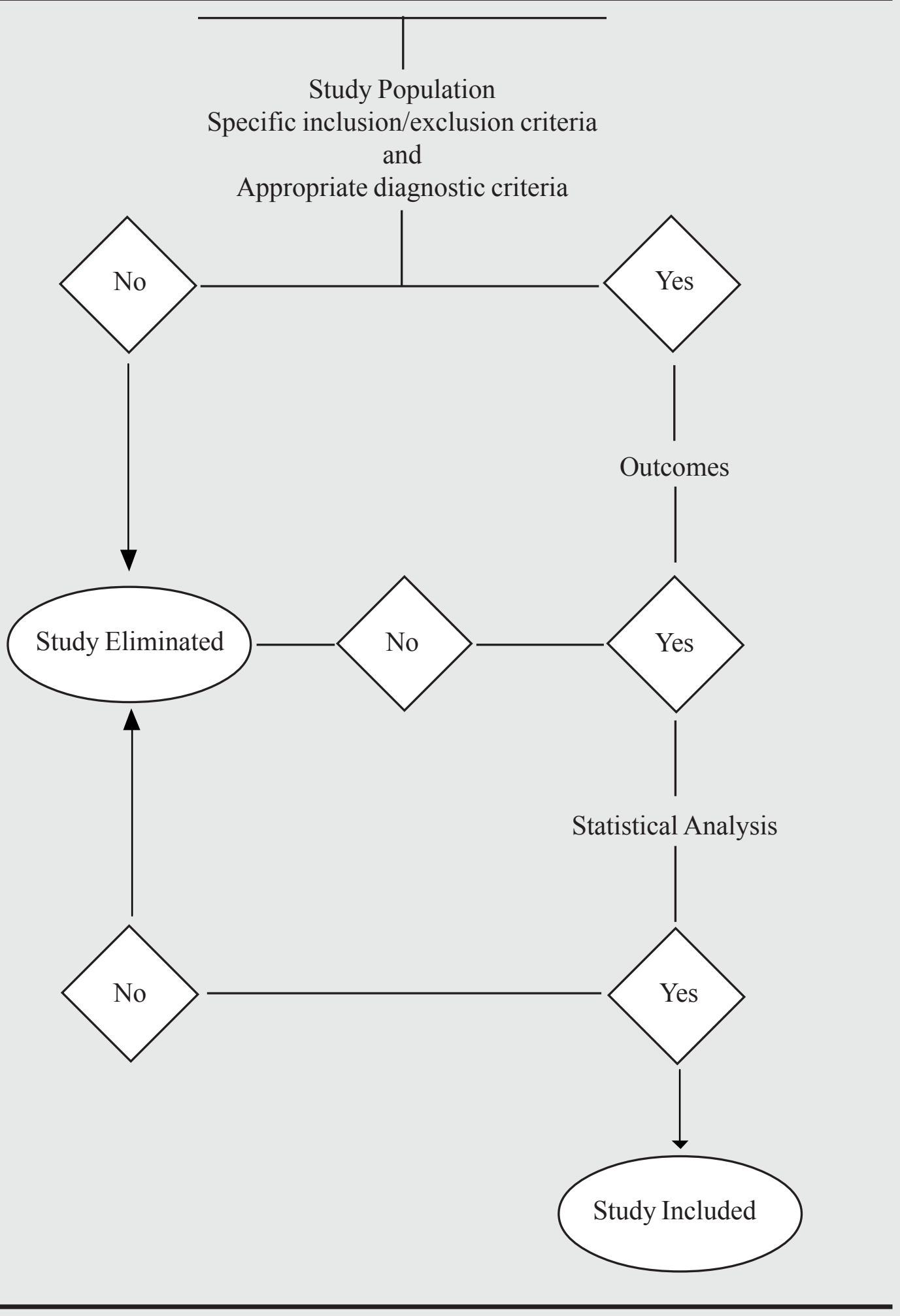


Table 2. Important domains and elements for systems to rate quality of individual articles

\begin{tabular}{lc}
\hline $\begin{array}{l}\text { Randomized Clinical Trials } \\
\text { (Seven Key Domains) }\end{array}$ & $\begin{array}{c}\text { Observational Studies } \\
\text { (Five Key Domains) }\end{array}$ \\
\hline Study question & Study question \\
Study population & Study population \\
Randomization & Comparability of subjects \\
Blinding & Exposure or intervention \\
Interventions & Outcome measurement \\
Outcomes & Statistical analysis \\
Statistical analysis & Results \\
Results & Discussion \\
Discussion & Funding or sponsorship \\
Funding or sponsorship & \\
\hline
\end{tabular}

* Key domains in italics with empirical basis. $\quad$ Adapted and modified from (81).

prospective and/or retrospective evidence.

Level III - Moderate: Evidence from a well-designed small randomized trial or evidence from well-designed trials without randomization, or quasi-randomized studies, single group, pre-post cohort, time series, or matched case-controlled studies or positive evidence from at least one meta-analysis.

Level IV - Limited: Evidence from well-designed nonexperimental studies from more than one center or research group

Level V - Indeterminate: Opinions of respected authorities, based on clinical evidence, descriptive studies, or reports of expert committees.

A consistent outcome was defined as a situation in which $60 \%$ or more studies agreed on the result of pain relief and/or improvement of functional status. Relief of 3-6 months was defined as short-term where as relief longer than 6 months was longterm.

\section{RESULTS}

Our search strategy identified over 1,000 citations as the result of electronic and manual screening.

\section{Randomized Trials}

A total of seven randomized trials of radiofrequency neu- rotomy for spinal pain were identified $(56,57,59,60,83-$ $85)$. Of these, only four related to medial branch neurotomy $(56,57,59,60)$. Among the other three, Sanders and Zuurmond (85) performed percutaneous intraarticular facet joint denervation, while the remaining two $(83,84)$ described radiofrequency lesioning of dorsal root ganglion.

The study population, as defined by the inclusion and exclusion criteria, consisted of patients with chronic neck or low back pain. Study quality evaluation showed that trials by Lord et al (56) and Van Kleef et al (57) have met all the key criteria and more than four of key domains. Study by Le Claire et al (60) failed to meet one of the key criteria, namely study population with descriptions of specific inclusion and exclusion criteria, as well as appropriate diagnostic evaluation and criteria for inclusion in the study. Even though this randomized evaluation met six of the seven key domains, it failed to meet one of the three criteria for inclusion, thus creating a fatal deficiency resulting in non-inclusion in this analysis. Study by Gallagher et al (59) was also not included, because it used the invalidated Shealy technique and such important aspects as the effects on physical impairment and disability were not investigated. Characteristics and results of randomized clinical trials included in analysis undergoing medial branch neurotomy is described in Table 3. Both studies showed positive short-term and long-term effects in a significant number of patients. 
Table 3. Description of randomized clinical trials included in the effectiveness analysis

\begin{tabular}{|c|c|c|}
\hline $\begin{array}{l}\text { Study \& } \\
\text { Authors }\end{array}$ & Lord et al 1996 (56) & Van Kleef et al 1999 (57) \\
\hline $\begin{array}{l}\text { Number of } \\
\text { patients }\end{array}$ & $\begin{array}{l}\text { Treatment }=12 \\
\text { Control }=12\end{array}$ & $\begin{array}{l}\text { Treatment }=15 \\
\text { Control }=16\end{array}$ \\
\hline $\begin{array}{l}\text { Description of } \\
\text { Patients }\end{array}$ & $\begin{array}{l}\text { Patients with neck pain of }>3 \text { months' duration, who } \\
\text { had pain in one or more cervical (C } 3-C 7 \text { ) } \\
\text { zygapophysial joints after a motor vehicle injury. } \\
\text { Zygapophysial joint involvement was confirmed by } \\
\text { placebo-controlled diagnostic blocks. Mean age } 44 \\
\text { years in treatment group, and } 43 \text { years in control } \\
\text { group. }\end{array}$ & $\begin{array}{l}\text { Patients with cLBP of }>12 \text { months' duration. } \\
\text { Conservative therapy attempted without success. } \\
\text { Absence of any neurologic deficit, and }>50 \% \text { pain relief } \\
\text { from a diagnostic dorsal ramus nerve blockade with a } \\
\text { local anesthetic solution. Mean age was } 46.6 \text { years in } \\
\text { treatment group and } 41.4 \text { years in control group. }\end{array}$ \\
\hline Objectives & $\begin{array}{l}\text { To evaluate the efficacy of RF denervation by } \\
\text { comparing it with a control procedure }\end{array}$ & $\begin{array}{l}\text { To assess the clinical efficacy of RF denervation of the } \\
\text { lumbar zygapophysial joints in reducing pain, functional } \\
\text { disability, and physical impairment in patients with back } \\
\text { pain. }\end{array}$ \\
\hline Intervention & $\begin{array}{l}\text { i. Radiofrequency lesion group was treated with a } \\
90 \text {-second RF lesion of } 80^{\circ} \mathrm{C} \text { of the medial branch } \\
\text { of the cervical dorsal ramus. } \\
\text { ii. In control or sham group, electrodes were } \\
\text { introduced as in treatment group, but no } \\
\text { radiofrequency lesion was made. }\end{array}$ & $\begin{array}{l}\text { i. Radiofrequency lesion group was treated with a } 60 \text { - } \\
\text { second RF lesion of } 80^{\circ} \mathrm{C} \text { of the medial branch of the } \\
\text { posterior primary ramus of the segmental nerves L3-L5. } \\
\text { ii. In control or sham group, electrodes were introduced } \\
\text { as in treatment group, but no radiofrequency lesion was } \\
\text { made. }\end{array}$ \\
\hline $\begin{array}{l}\text { Median duration } \\
\text { of pain in months } \\
\text { (range) }\end{array}$ & $\begin{array}{l}\text { Treatment }=44(23-94) \\
\text { Control }=34(25-92)\end{array}$ & $\begin{array}{l}\text { Treatment }=26(12-120) \\
\text { Control }=48(12-192)\end{array}$ \\
\hline Follow-up & $\begin{array}{l}3 \text { months } \\
6 \text { months } \\
12 \text { months }\end{array}$ & $\begin{array}{l}2 \text { months } \\
3 \text { months } \\
6 \text { months } \\
12 \text { months } \\
\end{array}$ \\
\hline Outcomes & $\begin{array}{l}\text { Success rate (a score of } 0-5 \text { out of } 100 \text { on VAS scale } \\
\text { a word count of }<3 \text { on the McGill Pain Questionnaire } \\
\text { and the restoration of all four activities of daily living. }\end{array}$ & $\begin{array}{l}\text { Number of successes }(\%)(>2 \text {-point reduction on VAS } \\
\text { scale and }>50 \% \text { reduction on global perceived effect) } \\
\text { Change in VAS mean, high, lowChange in Oswestry } \\
\text { Disability ScaleGlobal perceived effect }\end{array}$ \\
\hline Results & $\begin{array}{l}\text { i. Seven patients in treatment and one in control group } \\
\text { remained free of pain. The median time to return of } \\
\text { at least } 50 \% \text { of the preoperative level of pain was } 263 \\
\text { days in treatment group and } 8 \text { days in control group. } \\
\text { ii. Five patients in each study group underwent second } \\
\text { procedures. Three patients in the active-treatment } \\
\text { group, who had less than } 3 \text { months of relief after the } \\
\text { first procedure, did not have relief of their pain after } \\
\text { the second procedure. One patient in the control } \\
\text { group had no relief after either the initial procedure or } \\
\text { the "escape" procedure with active treatment. } \\
\text { iii. Success rate of } 75 \% \text { with one or two treatments. }\end{array}$ & $\begin{array}{l}\text { i. After } 8 \text { weeks of treatment, } 10 \text { of the } 15 \text { patients } \\
\text { undergoing radiofrequency were successful compared to } \\
6 \text { of the } 16 \text { in the control group. The differences in effect } \\
\text { on the visual analog scale scores, global perceived effect, } \\
\text { and the Oswestry Disability Scale were statistically } \\
\text { significant. } \\
\text { ii. After } 3 \text { months, the number of successes in the lesion } \\
\text { and sham groups were } 9 \text { and } 4(60 \% \text { vs. } 25 \%) \text { with } \\
\text { statistically significant difference ( } p=0.02) \text {. } \\
\text { iii. After } 6 \text { months, the number of successes in the lesion } \\
\text { and sham groups were } 7 \text { and } 3(47 \% \text { vs. } 19 \%) \text { with } \\
\text { statistically significant difference ( } p=0.02) \text {. } \\
\text { iv. After } 12 \text { months, the number of successes in the lesion } \\
\text { and sham groups were } 7 \text { and } 2 \text { respectively }(47 \% \text { vs. } \\
13 \% \text { ) with statistically significant difference (p = } 0.02) \text {. }\end{array}$ \\
\hline Study Conclusion & Positive long-term effect & Positive long-term effect \\
\hline
\end{tabular}


Table 4. Description and results of non-randomized prospective trials included in the analysis

\begin{tabular}{|c|c|c|c|c|}
\hline $\begin{array}{l}\text { Study } \\
\text { \&Author(s) }\end{array}$ & Dreyfuss et al 2000 (58) & Stoker et al 1993 (88) & Sapir \& Gorup (61) & McDonald et al (86) \\
\hline Objective(s) & $\begin{array}{l}\text { i. To establish the efficacy of lumbar medial branch } \\
\text { neurotomy under optimum conditions. } \\
\text { ii. To avoid shortcomings of the previous reports of } \\
\text { the efficacy of lumbar medial branch neurotomy } \\
\text { which have been confounded by poor patient } \\
\text { selection, inaccurate surgical technique and } \\
\text { inadequate assessment of outcome }\end{array}$ & $\begin{array}{l}\text { i. To evaluate effectiveness of } \\
\text { percutaneous facet denervation } \\
\text { and chronic thoracic spinal } \\
\text { pain. }\end{array}$ & $\begin{array}{l}\text { i. To assess the effect of monetary gain on } \\
\text { treatment of zygapophysial joint pain in cervical } \\
\text { whiplash. ii. To determine whether radiofrequency } \\
\text { medial branch neurotomy is effective treatment of } \\
\text { whiplash. }\end{array}$ & $\begin{array}{l}\text { i. To determine the long-term } \\
\text { efficacy of percutaneous } \\
\text { radiofrequency medial branch } \\
\text { neurotomy in the treatment of } \\
\text { chronic neck pain. }\end{array}$ \\
\hline $\begin{array}{l}\text { Description of } \\
\text { Patients }\end{array}$ & $\begin{array}{l}\text { i. Fifteen patients with chronic low back pain whose } \\
\text { pain was relieved by controlled, diagnostic medial } \\
\text { branch blocks of the lumbar zygapophysial joints, } \\
\text { underwent lumbar medial branch neurotomy. } \\
\text { ii. Before surgery, all were evaluated by visual } \\
\text { analog scale and a variety of validated measures of } \\
\text { pain, disability and treatment satisfaction.iii. A total } \\
\text { of } 460 \text { people responded to invitations to } \\
\text { participate in the study. After the interview, } 138 \\
\text { patients remained potentially eligible. After physical } \\
\text { examination, } 41 \text { patients remained potentially eligible } \\
\text { and proceeded to lumbar medial branch blocks. } \\
\text { Twenty-two patients who reported at least } 80 \% \\
\text { relief of pain for longer than one hour after the } \\
\text { lidocaine blocks underwent confirmatory blocks } \\
\text { using } 0.5 \% \text { bupivacaine. Fifteen of the twenty-two } \\
\text { patients undergoing bupivacaine blocks obtained at } \\
\text { least } 80 \% \text { relief of pain for longer than } 2 \text { hours and } \\
\text { were offered radiofrequency neurotomy. }\end{array}$ & $\begin{array}{l}\text { i. Forty patients with chronic } \\
\text { thoracic spinal pain of }>12 \\
\text { months duration which failed to } \\
\text { respond to conservative } \\
\text { treatment and with a previous } \\
\text { evaluation by a specialist, } \\
\text { mainly neurologists and } \\
\text { orthopedic surgeons, were } \\
\text { included. } \\
\text { ii. The diagnosis of facet } \\
\text { syndrome also was made by } \\
\text { clinical criteria and a transient } \\
\text { positive response to a } \\
\text { prognostic blockade of the } \\
\text { medial branch of the dorsal } \\
\text { ramus of the thoracic spinal } \\
\text { nerve. }\end{array}$ & $\begin{array}{l}\text { i. Fifty-nine patients underwent diagnostic blocks } \\
\text { of the cervical medial branch nerves of the } \\
\text { posterior primary ramus under fluoroscopic } \\
\text { imaging guidance using the controlled 2-phase } \\
\text { diagnostic method. } \\
\text { ii. The presence of zygapophysial joint pain was } \\
\text { confirmed if the blocks were successful. A block } \\
\text { was considered successful when the patient } \\
\text { obtained a greater than } 80 \% \text { reduction in self- } \\
\text { reported symptoms. Patients failed } 20 \text { weeks of } \\
\text { conservative management after cervical whiplash. } \\
\text { iii. The patients were classified as litigant or non- } \\
\text { litigant based on whether the potential for } \\
\text { monetary gain via litigation existed. Each group } \\
\text { underwent identical evaluation and treatment. } \\
\text { There were } 32 \text { patients in litigation group and } 18 \\
\text { patients in non-litigation group. } \\
\text { iv. Data was available from } 46 \text { patients for final } \\
\text { analysis with } 4 \text { exclusions or withdrawals. } \\
\text { v. Demographics and clinical characteristics } \\
\text { among litigants and non-litigants. }\end{array}$ & $\begin{array}{l}\text { i. Twenty-eight patients diagnosed } \\
\text { as having cervical zygapophysial } \\
\text { joint pain on the basis of } \\
\text { controlled diagnostic blocks were } \\
\text { included. }\end{array}$ \\
\hline Intervention & $\begin{array}{l}\text { i. Radiofrequency medial branch neurotomy was } \\
\text { performed under fluoroscopy with appropriate } \\
\text { needle placement after lidocaine infiltration at } 85^{\circ} \mathrm{C} \\
\text { for } 90 \text { seconds coagulating the target nerve } 8-10 \\
\text { mm along its length with } 2 \text { lesions. } \\
\text { ii. Lesioning was performed at } 2 \text { levels for each } \\
\text { joint. } \\
\text { iii. Electromyography of the multifidus muscle was } \\
\text { performed before and after surgery to ensure } \\
\text { accuracy of the neurotomy. }\end{array}$ & $\begin{array}{l}\text { i. Percutaneous radiofrequency } \\
\text { denervation of the facet joints } \\
\text { was carried out. }\end{array}$ & $\begin{array}{l}\text { i. All patients underwent the same diagnostic } \\
\text { procedural method for the 2-phase diagnostic } \\
\text { cervical medial branch blocks. } \\
\text { ii. Radiofrequency neurotomy was performed with } \\
\text { a Radionics lesion generator using a disposable } \\
\text { 22-gauge, } 100 \text {-mm, } 4 \text {-mm active tip RF lesioning } \\
\text { needles with two separate lesions at } 80^{\circ} \text { for } 90 \\
\text { seconds at each level denervated. }\end{array}$ & $\begin{array}{l}\text { i. Cervical radiofrequency of } \\
\text { zygapophysial joint nerves were } \\
\text { performed as described by Lord } \\
\text { et al ( } 56) \text {. } \\
\text { ii. The procedure was repeated } \\
\text { in patients whose pain recurred. }\end{array}$ \\
\hline Outcomes & $\begin{array}{l}\text { i. Outcomes were conducted at: } 6 \text { weeks, } 3 \\
\text { months, } 6 \text { months, and } 12 \text { months. } \\
\text { ii. Outcome measurements included } \\
\text { electromyography, lifting tasks, North American } \\
\text { Spine Society outcome instrument. }\end{array}$ & i. Pain relief & $\begin{array}{l}\text { i. The visual analog scale (VAS) ii. Self-report of } \\
\text { improvement (SRI)iii. Medication usage }\end{array}$ & $\begin{array}{l}\text { i. Outcome measures were the } \\
\text { proportion of patients who } \\
\text { responded to the initial procedure } \\
\text { and the duration of relief } \\
\text { subsequently obtained. } \\
\text { ii. Outcome was correlated with } \\
\text { the operator performing the } \\
\text { procedure, the type of electrode } \\
\text { used, litigation status, and the } \\
\text { type of diagnostic blocks used to } \\
\text { establish the diagnosis. }\end{array}$ \\
\hline Results & $\begin{array}{l}\text { i. Sixty percent of the patients obtained at least } \\
90 \% \text { relief of pain at } 12 \text { months. } \\
\text { ii. Eighty seven percent obtained at least } 60 \% \text { relief. } \\
\text { iii. Relief was associated with denervation of the } \\
\text { multifidus in those segments in which the medial } \\
\text { branches had been coagulated. } \\
\text { iv. Prelesion electrical stimulation of the medial } \\
\text { branch nerve with measurement of impudence was } \\
\text { no associated with outcome }\end{array}$ & $\begin{array}{l}\text { i. Forty patients underwent } 51 \\
\text { percutaneous thoracic facet } \\
\text { denervations. } \\
\text { ii. After } 2 \text { months, } 19 \text { patients } \\
(47.5 \%) \text { were pain free and } 14 \\
\text { patients }(35 \%) \text { had more than } \\
50 \% \text { pain relief, with a total of } \\
82.5 \% \text { of the patients reporting } \\
\text { greater than } 50 \% \text { relief. } \\
\text { iii. } 17.5 \% \text { of the patients had } \\
\text { no relief. } \\
\text { iv. With long-term follow-up of } \\
\text { average } 31 \text { months in } 36 \\
\text { [patients, } 44 \% \text { were pain-free } \\
\text { and } 39 \% \text { had more than } 50 \% \\
\text { pain relief, with a total of } 83 \% \\
\text { of the patients presenting } \\
\text { greater than } 50 \% \text { relief. } \\
\text { v. Adverse effects consisted of } \\
\text { postoperative pain in five } \\
\text { patients. }\end{array}$ & $\begin{array}{l}\text { i. The overall reduction in cervical whiplash } \\
\text { symptoms and visual analog pain scores were } \\
\text { insignificant immediately after treatment (non- } \\
\text { litigants vs litigants: } 2.0 \text { vs } 2.5, p=0.36 \text { ). } \\
\text { ii. At one year, the overall reduction in cervical } \\
\text { whiplash symptoms and visual analog pain scores } \\
\text { were significant (non-litigants vs litigants: } 2.9 \text { vs } \\
4.0, p=0.05 \text { ). } \\
\text { iii. One-year follow-up scores were higher than } \\
\text { immediate post-treatment scores (non-litigants vs. } \\
\text { litigants: } 2.5 \text { vs } 3.6 \text { ). } \\
\text { iv. The difference between litigants and non- } \\
\text { litigants in the degree of symptomatology or } \\
\text { response to treatment did not reach significance. } \\
\text { v. The potential for secondary gain in patients who } \\
\text { have cervical facet arthropathy as a result of a } \\
\text { whiplash injury does not influence response to } \\
\text { treatment. }\end{array}$ & $\begin{array}{l}\text { i. Complete relief of pain was } \\
\text { obtained in } 71 \% \text { of the patients } \\
\text { after an initial procedure. } \\
\text { ii. No patient who failed to } \\
\text { respond to a first procedure } \\
\text { responded to a repeat procedure, } \\
\text { but if pain returned after a } \\
\text { successful initial procedure, relief } \\
\text { could be reinstated by a repeat } \\
\text { procedure. } \\
\text { iii. The median duration of relief } \\
\text { after a first procedure was } 219 \\
\text { days when failures were included, } \\
\text { but } 422 \text { days when only } \\
\text { successful cases were } \\
\text { considered. } \\
\text { iv. The median duration of relief } \\
\text { after repeat procedure was at } \\
\text { least } 219 \text { days. } \\
\text { v. Outcome did not differ } \\
\text { according to the operator, the } \\
\text { type of electrode used, litigation } \\
\text { status, or the type of diagnostic } \\
\text { block used. }\end{array}$ \\
\hline $\begin{array}{l}\text { Study } \\
\text { Conclusion }\end{array}$ & Positive long-term effect & Positive long-term effect & Positive long-term effect & Positive long-term effect \\
\hline
\end{tabular}




\section{Observational Studies}

A number of observational studies were considered for inclusion. Results of the included studies are shown in Table 4. Among the observational studies, there were 4 prospective evaluations included in this systematic review $(58,61,86,87)$. Retrospective evaluations included 3 studies (88-90). Multiple studies were excluded as they failed to meet the criteria established for the inclusion.

Among the four prospective evaluations, Dreyfuss et al (58) described lumbar facet joint radiofrequency neurotomy in 15 patients utilizing strict criteria and procedural considerations. This study showed $60 \%$ improvement in $80 \%$ of the patients at one year. Stolker et al (87) studied thoracic facet joint neurolysis in 45 patients and reported positive results, $47.5 \%$ of the patients to be pain-free with an additional $35 \%$ with relief greater than $50 \%$ after two months. After a follow up of 18 to 54 (average 31 months in 36 cases) they reported $83 \%$ of the patients with greater than $50 \%$ pain relief. Sapir and Gorup (61) and McDonald et al (86) reported on their experience of cervical facet joint neurotomy. Sapir and Gorup (61) studied 46 patients. The overall reduction in cervical whiplash symptoms and visual analog pain scores were significant immediately after treatment and at one year in both litigant and non-litigant patients. McDonald et al (86) determined the long-term efficacy of percutaneous radiofrequency medial branch neurotomy in the treatment of chronic neck pain in 28 patients diagnosed as having cervical zygapophysial joint pain on the basis of controlled, diagnostic blocks. They reported complete relief of pain in $71 \%$ of the patients after an initial procedure. They reported that the median duration of relief after a first procedure was 219 days when failures were included, but 422 days when only successful were considered. The median duration of relief after repeat procedures was at least 219 days. Their results showed that radiofreqency neurotomy of the cervical zygapophysial joints significantly reduced headache severity in $80 \%$ of the patients, both at short-term and long-term follow-up. Thus, the present systematic review by including prospective trials showed the generalizability of the results which complement the results of controlled trials (68).

Among the retrospective studies included, all the studies showed significant improvement, thus, these results compliment the results of controlled trials, as well as prospective trials.

Among the retrospective evaluations, Tzaan and Tasker
(88) evaluated 118 consecutive percutaneous radiofrequency facet rhizotomies performed on 90 patients. They reported that with the first procedure, greater than $50 \%$ subjective reduction of pain was present in $41 \%$ overall patients with $37 \%$ of the cases done under local anesthesia, and $46 \%$ in cases done under general anesthesia with no significant difference noted. They also included cervical, thoracic and lumbosacral facets and noted no significant difference between the region involved or bilateral involvement. North et al (89) also evaluated radiofrequency lumbar facet denervation and analyzed prognostic factors. The long-term outcome was assessed by disinterested third party interview. Forty-five percent of patients undergoing denervation reported at least $50 \%$ relief of pain and long-term follow-up. However, they also reported that among the patients who only underwent temporary blocks, $13 \%$ reported relief by at least $50 \%$ at long-term follow-up. Schaerer (90) evaluated the value of radiofrequency facet rhizotomy in the treatment of patients with chronic neck and low back pain problems in 117 consecutive patients. They reported that overall results in 50 procedures were fair to excellent in $68 \%$ of the patients compared to $62 \%$ of the patients in the 71 lumbar rhizotomies with an average follow-up time of 13.7 months.

\section{Clinical Relevance of the Included Studies}

All of the studies described in the intervention underwent reasonable diagnostic process prior to radiofrequency neurotomy. They also described the interventions, results, and statistical analysis in a reasonable way. Studies not meeting the criteria were excluded. In the consideration of space, the references are provided for randomized trials only $(60,83-85)$.

\section{Analysis of Evidence}

In randomized trials $(56,57)$, the total of number of patients (combined for cervical and lumbar regions) in the treatment group was 27 compared to 28 in the control group. There was one dropout in the study by Van Kleef et al (57) and none in the study by Lord et al (56). Thus, the number of patients undergoing an intervention in two different regions has failed to meet the minimum required for a large randomized trial (at least 60 patients in smallest group). However, results were positive in both trials.

In prospective evaluations $(58,61,86,87)$, total number of patients studied were 133, with long-term relief ( $>6$ months) in $70 \%$ to $80 \%$ of the patients. The retrospective 
evaluations were all positive (89-91). Combined evidence of radiofrequency neurotomy of medial branches from randomized trials, complemented with non-randomized trials (prospective and retrospective evaluations) provided strong evidence of short-term relief and moderate evidence of longterm relief of chronic neck and low back pain.

\section{DISCUSSION}

In spite of the extensive data search, we found only four randomized controlled trials, of which two were considered to be of sufficient quality to be included in this systematic review. Thus, we have also included 4 prospective evaluations and an additional 3 retrospective evaluations in this analysis. All the studies included in the review, both randomized and non-randomized met the criteria. Several retrospective evaluations were excluded. Randomized, prospective, and retrospective studies showed positive outcomes in short-term, as well as long-term. All the studies included small number of patients except retrospective evaluations. The overall number of patients in both randomized trials was 55, of which 27 patients received active treatment. These studies were considered of high quality and properly performed despite inherent difficulty with such studies in recruiting patients, and obtaining funding. Lord et al (56) used placebo-controlled or comparative local anesthetic blocks. However, Van Kleef et al (57) used single local anesthetic which could result in false-positive diagnosis of facet joint pain.

Bogduk (66) responding to the systematic review by Geurts et al (62) defended the radiofrequency neurotomy and identified numerous deficiencies in the systematic review and difficulties with randomized trials. Bogduk (66) described that the tenure of the review was unfortunately nihilistic, and he defended radiofrequency therapy lest the articles be abused by organizations intent upon discrediting radiofrequency neurotomy. He felt that elimination from consideration of studies with fewer than 20 patients was egregious on two counts. He described that first it seems to be a convention among systematic reviewers to use a quality scale in which maximum points are accorded to studies with samples sizes of 100 and minimum points are accorded to studies with 50 patients. The second issue related to ethics which was not considered by the authors of the review. Thus, arbitrary sample sizes ignore the true test that is provided by the rules of statistics. However, the sample size is only one determinant of statistical power. Other variables include amount of pain relief, improvement in functional status, and the duration over which the pain relief and functional im- provement is sustained. Large numbers are feasible for drug trials and trials of physical therapy. However, these are not feasible, specifically in strictly controlled trials with one-year follow-up for interventional procedures, neither in academic nor in private practice settings. Thus, ethical, practical and pragmatic differences apply to the conduct of a double-blind studies of surgeries (66). Calling for "large numbers" on the basis of systems developed for conservative treatments of low risk is at best extremely difficult or even impossible, and fworst unethical when applied to interventional therapies. Further, some of the reviewers not aware of interventional pain management may also consider using local anesthetic in the control group as a non-placebo. Bogduk (66) described that the reasons for few studies in radiofrequency neurotomy are that there are precious few academics skilled in radiofrequency neurotomy who might be able to conduct placebo-control trials; however, most of those individuals have already contributed to the literature. Bogduk (66) added that private practitioners cannot be expected to conduct such trials. To do so without funding would constitute a financial suicide in the United States. In Bogduk's opinion, individuals in private practice have no chance of obtaining a grant unless they have a track record in research and he was not aware of such individuals with sufficient esteem to attract a grant successfully (66). Even when the study of Lord et al (56) was submitted as a grant application, it was denied funding on the grounds that the investigators had too poor a track record in research and that these patients with whiplash would not be relieved of their pain. Further, when a placebo-controlled study of lumbar radiofreqency neurotomy was proposed to the same body, it was officially deemed unnecessary on the grounds that we already had the results of Gallagher's study (59). Dreyfuss et al (58) proposed a double-blind controlled trial similar to the trial by Lord et al (56). However, this was not completed and was completed as a prospective evaluation due to multitude of reasons.

Hopwood and Manning (91) highlighted various drawbacks for a controlled trial of epidural steroids. Thus, in the United States, it is almost impossible to conduct the studies that authors in systematic reviews call for. The difficulties range from patient refusal to enroll in a placebo-controlled study as most patients believe that they will be allocated into a placebo group, most patients demand unblinding or withdraw from the study when they do not respond, unblinding after 12 months, 6 months or even after 3 months is a difficult venture, patients are not interested in undergoing extensive paperwork involved 
in these studies; referring physicians, patient attorneys, and third party payors uniformly deny participation in such studies. Further, credibility of any study sponsored by manufacturers of equipment or drug companies has been questioned. Thus, it is unfortunate that the rules of systematic evaluation by these reviewers portray the rules of modern evidence-based medicine mandating the inclusion of only randomized controlled trials contrary to the overwhelming evidence to include all types of evidence. Bogduk (66) also questioned the necessity and logic required for more than one study to prove that radiofrequency neurotomy is not a placebo.

Among the prospective studies, comparative local anesthetic or placebo-controlled blocks were used in two studies whereas in the other two studies, only single local anesthetic block was utilized. Long-term follow up was utilized in all the studies. Patients in all the studies suffered with chronic pain of long duration.

This review follows the originally defined evidence-based practice in terms of four basic contingencies: 1) recognition of patient problem and construction of a structured clinical question: 2) the ability to efficiently and effectively search the medical literature to retrieve the best available evidence to answer the clinical question: 3 ) critical appraisal of the evidence: and 4) integration of the evidence with all aspects of individual patient decision making to determine the best clinical care for the patient. Thus, this systematic review differs from a multitude of other systematic reviews in interventional pain management.

Systematic review is a type of scientific investigation of the literature on a given topic in which the "subjects" are the articles being evaluated. In contrast, a narrative review is similar to a systematic review but without all the safeguards to control against bias (92). Table 5 illustrates the differences between narrative and systematic reviews. Thus, before a research team conducts a systematic review, it develops a well-designed protocol that lists:

1. A focused study question,

2. A specific search strategy, including the database to be searched, and how studies will be identified and selected for the review according to inclusion and exclusion criteria,

3. The types of data to be extracted from each article, and

4. How the data will be synthesized, either as a text summary or as some type of quantitative aggregation or meta-analysis.

These steps are taken to protect the work against various

Table 5. Key distinctions between narrative and systematic reviews.

\begin{tabular}{|c|c|c|}
\hline Core Feature & Narrative Review & Systematic Review \\
\hline Study question & Often broad in scope & Often a focused clinical question. \\
\hline $\begin{array}{l}\text { Data sources and } \\
\text { search strategy }\end{array}$ & $\begin{array}{l}\text { Which databases were searched } \\
\text { and search strategy are not } \\
\text { typically provided. }\end{array}$ & $\begin{array}{c}\text { Comprehensive search of many databases as well } \\
\text { as the so-called gray literature. Explicit search } \\
\text { strategy provided. }\end{array}$ \\
\hline $\begin{array}{l}\text { Selection of articles } \\
\text { for study }\end{array}$ & $\begin{array}{l}\text { Not usually specified, potentially } \\
\text { biased. }\end{array}$ & Criterion-based selection, uniformly applied. \\
\hline $\begin{array}{l}\text { Article review } \\
\text { or appraisal }\end{array}$ & $\begin{array}{l}\text { Variable, depending on who is } \\
\text { conducting the review. }\end{array}$ & $\begin{array}{l}\text { Rigorous critical appraisal, typically using a data } \\
\text { extraction form. }\end{array}$ \\
\hline Study quality & $\begin{array}{l}\text { If assessed, may not use formal } \\
\text { quality assessment. }\end{array}$ & $\begin{array}{l}\text { Some assessment of quality is almost always } \\
\text { included as part of the data extraction process. }\end{array}$ \\
\hline Synthesis & Often a qualitative summary. & $\begin{array}{l}\text { Quantitative summary (meta-analysis) if the data } \\
\text { can be appropriately pooled; qualitative otherwise. }\end{array}$ \\
\hline Inferences & Sometimes evidence-based. & Usually evidence-based. \\
\hline
\end{tabular}


forms of unintended bias in the identification, selection, and use of published work in these reviews (92). The major difference between these two approaches synthesizing the clinical or scientific literature is that a systematic review attempts to minimize bias by the comprehensiveness and reproducibility of the search for and the selection of articles for review. The biases that can occur in systematic reviews are also similar to those that are possible in clinical studies. Thus, a good study design for randomized controlled trials requires that allocation to treatment or control be randomized with the investigator blinded to the subsequently assigned treatment known as allocation concealment. This helps to ensure comparability of study groups and minimizes selection bias (81). In systematic reviews, the literature search is not broad enough or the reasons for inclusion and exclusion of articles are not clearly specified, selection bias can arise in the choice of articles that are reviewed (92-94). Further, systematic reviews also typically focus on how well the study was designed, conducted and analyzed. Thus, systematic reviews are considered to provide a measure of quality for each study in the review. Systematic reviews comprise evidence based on research papers from the published literature and, whenever possible, from the "gray" or unpublished literature as well. However, much of the material identified are used for systematic reviews is from the peer-reviewed literature, the processes and thoroughness of review conducted by general reviewers and by those doing systematic reviews may not be the same. However, it is well known that systematic reviews yield different types of results.

In observational studies, some factor other than randomization determines treatment, assignment, or exposure. The two major types of observational studies are cohort and case-controlled studies. In a cohort study, a group is assembled and followed forward in time to evaluate an outcome of interest. The starting point for the follow-up may occur back in time (retrospective cohort) or at the present time (prospective cohort) (86). In either situation, participants are followed to determine whether they develop the outcome of interest. Conversely, for a casecontrolled study, the outcome itself is the basis for selection into the study. Previous interventions or exposures are then evaluated for all possible association with the outcome of interest. In all observation studies, selection of an appropriate comparison group of people without either the intervention/exposure of or the outcome of interest is generally the most important and the most difficult design issue. Ensuring the comparability of the treatment groups in a study is what makes the randomized controlled trial presumably a powerful research design. Observational studies are generally considered more liable to bias than randomized, clinical trials, but certain questions can be answered only by using observational studies.

Domains for rating the overall strength of body of evidence depends on quality, quantity and consistency. Overall quality of a body of scientific studies is influenced by study design, conduct, analysis or methodologic rigor. Quantity is a term which describes the extent to which there is a relationship between the technology or exposure being evaluated and outcome, as well as to the amount of information supporting that relationship. Three main factors contributing the quantity or the magnitude of effect (i.e., estimated effects such as mean differences, odds ratio, relative risk, or other comparative measures); the number of studies performed on the topic in question, (eg, only a few versus perhaps a dozen or more); and the number of individuals studied, aggregated over all the relevant and comparable investigations, which provides the width of the confidence limits for the different estimates.

Consistency is the degree to which a body of scientific evidence is in agreement with itself and with outside information. More specifically, a body of evidence is said to be consistent when numerous studies done in different populations using different study designs to measure the same relationship essentially similar or compatible results. This essentially means that the studies have produced reasonably reproducible results.

\section{CONCLUSION}

The studies reviewed provide strong evidence that radiofrequency denervation offers short-term, as well as long-term relief of pain, chronic neck, thoracic and low back pain of zygapophysial of facet joint origin. While the present "gold standard" is the large randomized controlled study, practical and ethical considerations as illustrated loom lagre in evaluation of interventional techniques. The present body of evidence presented in this review shows the effectiveness with a truly evidencebased medicine approach, which included not only the randomized trials, but also observational trials. Thus, while awaiting on conclusive evidence for radiofrequency neurotomy, the present review concludes that radiofrequency neurotomy of cervical, thoracic, or lumbosacral medial branches is an effective treatment for management of chronic spinal pain. 


\section{REFERENCES}

1. Manchikanti L, Singh V, Kloth D et al. Interventional techniques in the management of chronic pain: Part 2.0. Pain Physician 2001; 4:24-96.

2. Lawrence RC, Helmick CG, Arnett FC. Estimates of the prevalence of arthritis and selected musculoskeletal disorders in the United States. Arthritis \& Rheumatism 1998; 41:778-799.

3. Manchikanti L, Saini B, Singh V. Epidemiology of low back pain. In Manchikanti L, Slipman CW, Fellows B (eds), Interventional Pain Management: Low Back Pain: Diagnosis and Treatment. ASIPP Publishing, Paducah, KY 2002 pp 3-20.

4. Cassidy D, Carroll L, Cote P: The Saskatchewan Health and Back Pain Survey. The prevalence of low back pain and related disability in Saskatchewan Adults. Spine 1998; 23:1860-1867.

5. Côté DC, Cassidy JD, Carroll L. The Saskatchewan Health and Back Pain Survey. The prevalence of neck pain and related disability in Saskatchewan adults. Spine 1998; 23:1689-1698.

6. Côté DC, Cassidy JD, Carroll L. The factors associated with neck pain and its related disability in the Saskatchewan population. Spine 2000; 25:1109-1117.

7. Croft PR, Lewis M, Papageorgiou AC et al. Risk factors for neck pain: A longitudinal study in the general population. Pain 2001; 93:317-325.

8. Johnson G. Hyperextension soft tissue injuries of the cervical spine: A review. J Accid Emerg Med 1996; 13:3-8.

9. Linton SJ, Hellsing AL, Hallden K. A population based study of spinal pain among 35-45-year old individuals. Spine 1998; 23:1457-1463.

10. Edmondson SJ, Singer KP. The thoracic spine: Anatomical and biomechanical considerations for manual therapy. Man Ther 1997; 2:132-143.

11. Occhipiniti E, Colombini D, Grieco A. Study of distribution and characteristics of spinal disorders using a validated questionnaire in a group of male subjects not exposed to occupational spinal risk factors. Spine 1993; 18:1150-1159.

12. Anderson R, Meeker WC, Wieick BE et al. A metaanalysis of clinical trials of spinal manipulation. JMPT 1992; 15:181-194.

13. Singer KP, Edmondston SJ. Introduction: The enigma of the thoracic spine. In Giles GF, Singer KP (eds). Clinical Anatomy and Management of Thoracic Spine Pain. Butternorth Heineman, Boston, 2000; pp 315.

14. Kuslich SD, Ulstrom CL, Michael CJ. The tissue origin of low back pain and sciatica: A report of pain response to tissue stimulation during operation on the lumbar spine using local anesthesia. Orthop Clin North Am 1991; 22:181-187.

15. Goldthwait JE. The lumbosacral articulation: An explanation of many cases of lumbago, sciatica, and paraplegia. Boston Med and Surg J 1911; 164:365372.

16. Bogduk N. International Spinal Injection Society guidelines for the performance of spinal injection procedures. Part 1: Zygapophysial joint blocks. Clin J Pain; 1997; 13:285-302.

17. Mooney V, Robertson J. The facet syndrome. Clin Orthop 1976; 115:149-156.

18. McCall IW, Park WM, O'Brien JP. Induced pain referral from posterior lumbar elements in normal subjects. Spine 1979; 4:441-446.

19. Dwyer A, Aprill C, Bogduk N. Cervical zygapophyseal joint pain patterns I: A study in normal volunteers. Spine 1990; 15:453-457.

20. Dreyfuss P, Tibiletti C, Dreyer SJ. Thoracic zygapophyseal joint pain patterns: A study in normal volunteers. Spine 1994; 19:807-811.

21. Marks R. Distribution of pain provoked from lumbar facet joints and related structures during diagnostic spinal infiltration. Pain 1989; 39:37-40.

22. Fukui S, Ohseto K, Shiotani M et al. Distribution of referral pain from the lumbar zygapophyseal joints and dorsal rami. Clin J Pain 1997; 13:303-307.

23. Fukui S, Ohseto K, Shiotani M et al. Referred pain distribution of the cervical zygapophyseal joints and cervical dorsal rami. Pain 1996; 68:79-83.

24. Aprill C, Dwyer A, Bogduk N. The prevalence of cervical zygapophyseal joint pain patterns II: a clinical evaluation. Spine 1990; 6:458-461.

25. Pawl RP. Headache, cervical spondylosis, and anterior cervical fusion. Surg Ann 1977; 9:391-498.

26. Bogduk N. The clinical anatomy of the cervical dorsal rami. Spine 1982; 7:319-330.

27. Suseki K, Takahashi Y, Takahashi K, et al. Innervation of the lumbar facet joints. Spine 1997; 22:477485 .

28. Bogduk N, Wilson AS, Tynan W. The human lumbar dorsal rami. J Anat 1982; 134:383-397.

29. Chua WH, Bogduk N. The surgical anatomy of thoracic facet denervation. Acta Neurochir 1995; 136:140-144.

30. Stilwell DL. The nerve supply of the vertebral column and its associated structures in the monkey. Anat Rec 1956; 125:139-169.

31. Bogduk N, Holmes S. Controlled zygapophysial joint blocks: The travesty of cost-effectiveness. Pain Med 2000; 1:24-34.

32. Schwarzer AC, Wang S, O'Driscoll et al. The ability of computed tomography to identify a painful zygapophysial joint in patients with chronic low back pain. Spine 1995; 20:907-912.

33. Schwarzer AC, Derby R, Aprill CN et al. Pain from the lumbar zygapophysial joints: A test of two models. J Spinal Disord 1994; 7:331-336.

34. Manchikanti L, Pampati V, Fellows B et al. The in- 
ability of the clinical picture to characterize pain from facet joints. Pain Physician 2000; 3:158-166.

35. Merskey H, Bogduk N. Classification of chronic pain: Descriptions of chronic pain syndromes and definitions of pain terms. Second Edition. IASP Press, Seattle, 1994.

36. Schwarzer AC, Aprill CN, Derby R et al. Clinical features of patients with pain stemming from the lumbar zygapophysial joints. Is the lumbar facet syndrome a clinical entity? Spine 1994; 19:1132-1137.

37. Schwarzer AC, Wang S, Bogduk N et al. Prevalence and clinical features of lumbar zygapophysial joint pain: A study in an Australian population with chronic low back pain. Am Rheum Dis 1995; 54:100-106.

38. Manchikanti L, Pampati VS, Fellows B et al. Prevalence of lumbar facet joint pain in chronic low back pain. Pain Physician 1999; 2:59-64.

39. Manchikanti L, Pampati VS, Bakhit CE et al. The diagnostic validity and therapeutic value of lumbar facet joint nerve blocks with or without adjuvant agents. Cur Rev Pain 2000; 4:337-344.

40. Manchikanti L, Singh V, Pampati VS et al. Evaluation of the relative contributions of various structures in chronic low back pain. Pain Physician 2001; 4:308-316.

41. Barnsley L, Lord SM, Wallis BJ et al. The prevalence of chronic cervical zygapophyseal joint pain after whiplash. Spine 1995; 20:20-26.

42. Lord SM, Barnsley L, Wallis BJ et al. Chronic cervical zygapophysial joint pain with whiplash: A placebocontrolled prevalence study. Spine 1996; 21:17371745.

43. Manchikanti L, Singh V, Rivera J et al. Prevalence of cervical facet joint pain in chronic neck pain. Pain Physician 202; 5:243-249.

44. Manchikanti L, Pampati V, Beyer C et al. Evaluation of the prevalence of thoracic facet joint pain in chronic thoracic pain. Pain Physician 2002; 5:354-359.

45. Bogduk N, Lord S. Cervical zygapophysial joint pain. Neurosurgery 1998; 8:107-117.

46. Barnsley L, Lord S, Bogduk N. Comparative local anesthetic blocks in the diagnosis of cervical zygapophysial joints pain. Pain 1993; 55: 99-106.

47. Lord SM, Barnsley L, Bogduk N. The utility of comparative local anesthetic blocks versus placebo-controlled blocks for the diagnosis of cervical zygapophysial joint pain. Clin J Pain 1995; 11:208213.

48. Barnsley L, Lord S, Wallis B et al. False-positive rates of cervical zygapophysial joint blocks. Clin J Pain 1993; 9:124-130.

49. Schwarzer AC, Aprill CN, Derby R et al. The falsepositive rate of uncontrolled diagnostic blocks of the lumbar zygapophysial joints. Pain 1994; 58:195-200.

50. Carette S, Marcoux S, Truchon R et al. A controlled trial of corticosteroid injections into facet joints for chronic low back pain. N Engl J Med 1991; 325:10021007.

51. Barnsley L, Lord SM, Wallis BJ et al. Lack of effect of intra-articular corticosteroids for chronic pain in the cervical zygapophyseal joints. NEngl J Med 1994; 330:1047-1050.

52. Lilius G, Laasonen EM, Myllynen P et al. Lumbar facet joint syndrome. A randomized clinical trial. $J$ Bone Joint Surg (Br) 1989; 71:681-684.

53. Marks RC, Houston T, Thulbourne T. Facet joint injection and facet nerve block. A randomized comparison in 86 patients with chronic low back pain. Pain 1992; 49:325-328.

54. Nash TP. Facet joints. Intra-articular steroids or nerve blocks? Pain Clinic 1990; 3:77-82.

55. Manchikanti L, Pampati VS, Bakhit C et al. Effectiveness of lumbar facet joint nerve blocks in chronic low back pain: A randomized clinical trial. Pain Physician 2001; 4:101-117.

56. Lord SM, Barnsley L, Wallis BJ et al. Percutaneous radio-frequency neurotomy for chronic cervical zygapophyseal-joint pain. $N$ Eng $J$ Med 1996; 335:1721-1726.

57. Van Kleef M, Barendse GAM, Kessels A et al. Randomized trial of radiofrequency lumbar facet denervation for chronic low back pain. Spine 1999; 24:1937-1942.

58. Dreyfuss P, Halbrook B, Pauza K et al. Efficacy and validity of radiofrequency neurotomy for chronic lumbar zygapophysial joint pain. Spine 2000; 25:12701277.

59. Gallagher J, Vadi PLP, Wesley JR. Radiofrequency facet joint denervation in the treatment of low back pain - A prospective controlled double-blind study to assess efficacy. Pain Clinic 1994; 7:193-198.

60. Leclaire R, Fortin L, Lambert R et al. Radiofrequency facet joint denervation in the treatment of low back pain: a placebo-controlled clinical trial to assess efficacy. Spine 2001; 26:1411-1417.

61. Sapir D, Gorup JM. Radiofrequency medial branch neurotomy in litigant and nonlitigant patients with cervical whiplash. Spine 2001; 26:E268-E273.

62. Geurts JW, van Wijk RM, Stolker RJ et al. Efficacy of radiofrequency procedures for the treatment of spinal pain: A systematic review of randomized clinical trials. Reg Anesth Pain Med 2001; 26:394-400.

63. Gonzalez EG, Materson RS (eds). The nonsurgical management of acute low back pain. Demos Vermande, New York, 1997.

64. Nachemson AL, Jonsson E (eds). Neck and back pain. The scientific evidence of causes, diagnosis, and treatment. Lippincott Williams \&Wilkins, Philadelphia, 2000.

65. Manchikanti L. Evidence-based interventional pain medicine: Is there any evidence? Pain Physician 2002; $5: 1-7$. 
66. Bogduk N. In defense of radiofrequency neurotomy. Letter to the editor. Reg Anesth Pain Med 2002; 27:439-447.

67. Manchikanti L, Jasper J, Singh V. Cochrane review by Nelemans et al. Spine 2001; 26:2641-2643.

68. Guyatt G, Rennie D (eds). User's Guides to the Medical Literature. A manual for evidence-based clinical practice. AMA Press, 2002.

69. Stroup DF, Berlin JA, Morton SC et al. Meta-analysis of observational studies in epidemiology. JAMA 2000; 283:2008-2012.

70. Stroup DF, Thacker SB, Olson CM et al. Characteristics of meta-analyses submitted to a medical journal. From: International Congress on Biomedical Peer Review and Global Communications; Prague, Czech Republic; September 17-21, 1997.

71. Greenland S. Invited commentary. Am J Epidemiol 1994; 140:290-296.

72. Lau J, Ioannidis JP, Schmid CH. Summing up evidence. Lancet 1998; 351:123-127.

73. Shapiro S. Meta-analysis/Shmeta-analysis. Am J Epidemiol 1994; 140:771-778.

74. Berlin JA. Invited commentary. Am J Epidemiol 1995; 142:383-387.

75. Peipert JF, Phipps MG. Observational studies. Clin Obstet Gynecol 1998; 41:235-244.

76. Mann CC. Can meta-analysis make policy? Science 1999; 266:960-962.

77. Kepes ER, Duncalf D. Treatment of backache with spinal injections of local anesthetics, spinal and systemic steroids. Pain 1985; 22:33-47.

78. Koes BW, Scholten RJPM, Mens JMA et al. Efficacy of epidural steroid injections for low back pain and sciatica: A systematic review of randomized clinical trials. Pain 1995; 63:279-288.

79. Koes BW, Scholten R, Mens JMA et al. Epidural steroid injections for low back pain and sciatica. An updated systematic review of randomized clinical trials. Pain Digest 1999; 9:241-247.

80. Nelemans PJ, Debie RA, DeVet HC et al. Injection therapy for subacute and chronic benign low back pain. Spine 2001; 26:501-515.

81. Systems to rate the strength of scientific evidence. Evidence Report/Technology Assessment No. 47 University of North Carolina: Agency for Healthcare Research and Quality. AHRQ Publication No. 02-E015; 2002.

82. Sacks HS, Reitman D, Pagano D et al. Meta-analysis: An update. Mt Sinai J Med 1996; 63:216-224.
83. van Kleef $\mathrm{M}$, Liem L, Lousberg $\mathrm{R}$ et al Radiofrequency lesion adjacent to the dorsal root ganglion for cervicobrachial pain: A prospective double blind randomized study. Neurosurgery 1996; 38:1127-1131

84. Slappendel R, Crul BJ, Braak GJ et al. The efficacy of radiofrequency lesioning of the cervical spinal dorsal root ganglion in a double blinded randomized study: No difference between $40^{\circ} \mathrm{C}$ and $67^{\circ} \mathrm{C}$ treatments. Pain 1997; 73:159-163.

85. Sanders M, Zuurmond WWA. Percutaneous intraarticular lumbar facet joint denervation in the treatment of low back pain: A comparison with percutaneous extra-articular lumbar facet denervation. Pain Clin 1999; 11:329-335.

86. McDonald GJ, Lord SM, Bogduk N. Long-term follow-up of patients treated with cervical radiofrequency for chronic neck pain. Neurosurgery $1999 ; 45$;14991450.

87. Stolker RJ, Vervest AC, Groen GJ. Percutaneous facet denervation in chronic thoracic spinal pain. Acta Neurochir 1993; 122:82-90.

88. Tzaan WC, Tasker RR. Percutaneous radiofrequency facet rhizotomy - experience with 118 procedures and reappraisal of its value. Can J Neurol Sci 2000; 27:125-130.

89. North RB, Han M, Zahurak M et al. Radiofrequency lumbar facet denervation: Analysis of prognostic factors. Pain 1994; 57:77-83.

90. Schaerer JP. Radiofrequency facet rhizotomy in the treatment of chronic neck and low back pain. Int Surg 1978; 63:53-59.

91. Hopwood MB, Manning DEC. Lumbar epidural steroid injections: Is a clinical trial necessary or appropriate. Reg Anesth Pain Med 1999; 24:5-7.

92. Cook DJ, Mulrow CD, Haynes RB. Systematic reviews: Synthesis of best evidence for clinical decisions. Ann Intern Med 1997; 126:376-380.

93. Mulrow CD. The medical review article: State of the science. Ann Intern Med 1987; 106:485-488.

94. Clark HD, Wells GA, Huet $\mathrm{C}$ et al. Assessing the quality of randomized trials: Reliability of the Jadad scale. Control Clin Trials 1999; 20:448-452.

95. McQuay H, Moore A (eds). An evidence-based resource for pain relief. Oxford University Press, New York, 1998. 